\title{
GLASBENO-ANALITIČNI NASTAVKI: K POJMOVANJU DESKRIPCIJE TONSKEGA STAVKA
}

Zdi se sicer samoumevno, da je bilo razčlenjevanje glasbenega stavka v posameznih zgodovinskih obdobjih podvrženo različnim kriterijem, obenem pa ni mogoče zanikati določenih analitičnih stalnic. Od antike do 19. stoletja se glasbeno-analitični nastavki tako iztekajo $\mathrm{v}$ tri zgodovinsko bolj ali manj zamejene "postaje". Toda klasifikacijo gre razumeti kot metodološko poenostavljeno razmejitev temeljnih analitičnih postavk, ki se ne izključujejo, temveč so se skozi zgodovino medsebojno bolj ali manj prepletale. Denimo:

1. za antiko je značilno predvsem razkrivanje tonskega sistema po analogijah z univerzalnimi aritmetičnimi principi, kar je razvidno iz zapuščine platonističnopitagorejske tradicije;

2. za pisce srednjega veka in renesanse je pomembno razkrivanje tonskega sistema po analogijah z ustrojem jezika. Lahko govorimo o glasbeni gramatiki, ki tvori osnovo kompozicijsko-analitične refleksije vsaj od prvih ohranjenih traktatov o večglasju in vsaj do baročnega nauka o figurah oziroma afektih. Vendar tako v Musici in Scolici enchiriadis kot pri J. Tinctorisu in G. Zarlinu, torej petsto oziroma šesto let kasneje, ostajajo univerzalni aritmetični principi urejanja tonskega sistema osnova analitične obravnave;

2.1. ob glasbeni gramatiki je v obdobju baroka zaslediti vse pogostejši poudarek na pomenu, smislu, konotacijah, "intencah", "vsebini" posamezne tonske postavitve. Lahko govorimo o glasbeni retoriki, o analitičnem opazovanju tonskih rešitev po analogijah s semantično lažje opredeljivim svetom pojmov. Obenem pa je pozornost glasbenih piscev osredotočena na pravila glasbene gramatike in na razkrivanje univerzalnib (t.j. aritmetičnib) kompozicijsko-analitičnih vodil, značilnih za kompozicijo v modalnem oziroma v lestvičnem sistemu. 
3. V drugi polovici 18. stoletja je središče analitičnega opazovanja klasicistična "periodologija" (H.Ch. Koch), ki jo skupaj z navedenimi analitiškimi postajami kaže razumeti kot enega izmed temeljnih indikatorjev pomena tonske zgradbe, ki - v različnih preoblekah - živijo tudi $\mathrm{v}$ današnjih analitičnih pristopih. Klasicistični "mehanski" kompozicijsko-analitični nauk, za katerega je značilno, da je v 19. stoletju postal sumljiv preskriptivni pripomoček kompozicijskih šol, je z oblikoslovjem 19. stoletja postal sumljiv skupek vzorcev za opisovanje tonske zgradbe, ki sicer ponuja vpogled v "obrtniško" plat, vendar komajda zadošča razumevanju "umetniškega", "poetičnega", "visokega". Priostreno rečeno: $z$ analitično prakso, ki izhaja iz nauka o oblikah A.B. Marxa, glasbeno delo postaja predmet dvotirnega analitičnega opazovanja; po eni plati analitik s pomočjo oblikoslovja razkriva mreže motivično-tematskega in harmonskega pletiva, iz katerega skladatelj "gradi svoj svet" (E.T.A. Hoffmann), po drugi plati pa obravnava skladbo kot estetsko tvorbo, ki postulira približevanje skladateljevemu "sublimnemu jeziku", "retoriki" ali "jeziku" čustev, v tonih "izraženemu neizrečenemu" ipd.

Antinomija med "obliko" in "vsebino", ki je ostala predmet odmevnih estetičnih polemik še posebej od Hanslickovega spisa Vom Musikalisch-Schönen (1854) dalje, je pri tvorcu današnjega oblikoslovja A.B. Marxu temeljila v prepričanju, da so vzvodi estetskega oblikovanja analogon določenim naravnim principom. In ne v njih, temveč v vsakokratnem preoblikovanju določenih oblikotvornih vzorcev naj skladatelj oziroma analitik išče enkratno, neponovljivo umetnost iznajdevanja "duhovnih izrazil". (Kasneje je v svoji analitični teoriji Heinrich Schenker - z geslom: semper idem sed eodem modo - poveličeval ravno to značilnost glasbenega jezika, namreč moč preoblikovanja istega, kar je do danes ostala stalnica pri različnih avtorjih od H. Riemanna, H. Leichtentritta do D. de la Mottea.) Teoretična "razmejena obravnava različnih glasbenih prvin (melodike harmonije itn.)," tako meni Marx, je "odtujena bistvu umetnosti in je ne kaže izvajati." Marx je torej zagovarjal holistični pristop, ki ne razkriva le posameznih segmentov glasbenega stavka in jih selekcionira po posameznih "pravilnih" ali "izjemnih" shemah, temveč skuša zaobjeti celoto posameznosti kot pojavno obliko določenih "duhovnih vsebin", kakršne omogoča "narava glasbe" in jih je mogoče opisovati le v prispodobah.

Iz Marxove temeljne analitične drže je mogoče izpostaviti vsaj dva glavna postulata: 1 . da naj analitik v skladbi razkriva mrežo razmerij med glasbenimi prvinami in 2. naj skuša zaobjeti in opisati umetniške rešitve, ki pričajo o "duhovnem vzorcu" določenega glasbenega dela. Oba Marxova postulata do danes nista izgubila aktualnosti. ${ }^{2}$ Kljub temu pa tako formulirano področje glasbeno-stavčne (oblikovne)

1 Die Lehre von der musikalischen Komposition I, cit. po devetem ponatisu v redakciji Huga Riemanna, Leipzig $1887,8$.

2 Vsaka analitična metoda se nujno sooča $\mathrm{z}$ vprašanji natančnega razkrivanja tonskega tkiva po eni plati in, po drugi, z vprašanji razkrivanja teoretičnega "ozadja" ("duhovnega vzorca") določene glasbene zgradbe. 
analize posega na področje celostne analize glasbenib pojavov - na področje razkrivanja ne le zvočne zgradbenosti, temveč tudi njenega teoretičnega ozadja. In na tej točki je videti glavno vozlišče glasbeno-analitičnih pristopov: vprašanje o razmerju med oblikovno analizo (razkrivanjem značilnosti glasbenega stavka) in "duhovnem, naravnem principu", v okviru katerega je mogoče govoriti o vsebini, vsebinskosti, pomenu ipd. določene tonske podobe.

Namen tega spisa ni obravnava razlik med pojmi kot so vsebina-vsebinskost ali glasbeni smisel-pomen - zato jih $\mathrm{v}$ nadaljevanju kaže razumeti kot pomensko razmeroma diferencirane pojme, ki $\mathrm{v}$ različnih jezikovnih okoljih predstavljajo razmerja med pojavnostjo in njej pripisanim pomenom. Rdečo nit tega sestavka pojem deskripcije tonskega stavka - je tako razumeti kot razmislek o nekaterih definicijah "pomenskotvornih kontekstov", t.j. nekaterih epistemoloških nastavkov razčlenjevanja glasbene zgradbe.

\section{Opisovanje ali opisovanja glasbenega stavka.}

V novejši literaturi je skorajda samoumevno, da je treba razlikovati med izhodiščnim klasičnim oblikoslovjem in deskriptivno morfologijo ("fenomenologijo") glasbenih oblik, kakršno zagovarja denimo Peter Faltin. ${ }^{3}$ Clemens Kühn v svojem Oblikoslovju, enem najvplivnejših nemških učbenikov analize $\mathrm{v}$ zadnjem desetletju, postulira analitično opazovanje tudi glasbe klasicistično-romantičnega obdobja po deskriptivnih oblikotvornih vodilih: ponavljanje, variante, različnost, kontrastnost, nepovezanost, grupiranje ipd. in opozarja na omejujočo nomenklaturo klasičnega oblikoslovja. ${ }^{4}$ Čeprav avtor poudarja zgodovinsko pogojenost pojma deskripcije, v svojem učbeniku ne posveča posebne pozornosti konsekvencam, ki jih načelo deskripcije uvaja $\mathrm{v}$ analitično prakso.

Pojem deskriptivnega reflektiranja o glasbi bi lahko ponazorili ob krajši primerjavi dveh skupkov priporočil za analizo. Prvega je Dieter de la Motte dodal k svojim vzorčnim analizam, ${ }^{5}$ druge pa H.H. Eggebrecht v svoji študiji o Razumevanju glas$b e^{6}$. Oba, še posebej na nemško govorečem področju vplivna avtorja, priporočata, da je pri razčlenjevanju tonske zgradbe treba izhajati iz prve slušne izkušnje. Razlika med obema avtorjema se pokaže pri naslednjem koraku analiziranja. Eggebrecht - v skladu s svojim teoretičnim sistemom, v katerem estetska zaznava bolj ali manj učinkovito "opozarja" na spoznavno (v teoriji utemeljeno) ozadje obravnavane skladbe - vidi nevarnost v tem, da je deskriptivna analiza stavčnega ustroja sicer primarna, vendar da ravno "zunajglasbeni dejavniki [...] obogatijo

\footnotetext{
3 Phänomenologie der musikalischen Form, Beihefte zum AfMW, Wiesbaden 1979.

4 Formenlehre in der Musik, Bärenreiter 1987 (po 3. izd., 1992), 8.

5 Musikalische Analyse, (peti ponatis Bärenreiter 1987).

6 Musik Verstehen, Piper 1995, 134-6.
} 
razumevanje, tako da razkrijejo perspektive, ki jih estetska zaznava zgolj delno razkrije, ali pa sploh ne". ${ }^{7}$ Eggebrechtovo stališče torej kaže razumeti kot eno izmed pričevanj o nalogi analitika, ki naj smiselno (!) predstavi določeno skladbo (Žanr, opus, slog); potem je število možnih analitičnih vprašanj, kot meni avtor, nezamejeno, oziroma vpeto $\mathrm{v}$ postulate določenih gnoseoloških predpostavk. Nasprotno pa de la Motte svari pred "preinterpretacijo" (22. napotek) - zagovarja stališče, da so zgodovinsko-teoretična vodila analizirane skladbe tista, ki naj funkcionirajo kot orientirna točka analitičnega dela:

"Varuj se preinterpretiranja. Če razkriješ v skladbi, ki je nastala v času med [H.] Schützem in Mahlerjem vse prvine melodičnih tonskih lestvic in trizvočij, preostane komajda kaj drugega. In pri mizernih skladbah ni odstotek [analitičnih izsledkov] nič manjši, kakor pri mojstrovinah" (21).

Avtor torej izhaja iz stališča učbenikov oblikoslovja s podnaslovom "za praktike". Skladbo obravnava kot estetsko zaključeno celoto, ki od nastanka dalje živi kot v sebi popoln in recepcijsko nespremenljiv skupek oblik. Analitik naj ga obravnava kot mrežo harmonskih in motivičnih povezav, $\mathrm{v}$ skladu $\mathrm{z}$ današnjo predstavo o oblikoslovju, harmoniji in kontrapunktu. (Kot "analizo brez predpostavk" je de la Motte označil razčlenbo oblikovnega poteka miniature za klarinet in klavir A. Berga op.5/1.) Če je to za de la Mottea cilj analize, pa Eggebrecht uvršča tovrstno oblikovno analizo v poglavje o "spoznavnem" razumevanju: analiza ustroja tonskih prvin ali "analiza oblikovanja" (Formungsanalyse, 8.napotek) je po Eggebrechtu lahko docela smiselna, vendar vztraja, da se že v besednjaku, ki je značilen za oblikovno analizo, neizogibno kaže soočanje z zgodovinsko zamejeno vsebinskostjo (Gehalt) oziroma "od zunaj" pripisano sporočilnostjo, kar naj upošteva vsako analitično delo.

V delih H. Schütza, naprimer (de la Motte Schütza ne obravnava), torej v skladbah, nastalih $\mathrm{v}$ idejnem okolju baročne teorije figur ali afektov, po katerem je glasba analogon govoru retorika, je analiza melodike v smislu oblikoslovja A.B. Marxa torej razčlenjevanja, kakršnega postulira de la Motte -, vsaj vprašljiva, če ne pomankljiva. Analitično opazovanje Schützove melodike, pri katerem bi odmislili bodisi baročno teorijo afektov in skladateljevo vokalno in instrumentalno poetiko, bodisi danes aktualne semiološke oziroma hermenevtične interpretacije glasbene vsebinskosti - torej analiza glasbene "gestike" ali "tektonske intence" (P. Faltin) -, bi bilo smiselno predvsem pri raziskovanju glasbene recepcije.

Zdi se samoumevno, da določeno teoretično izhodišče $\mathrm{v}$ osnovi izhaja iz kompozicijsko-analitične prakse posameznega obdobja (in da je oznaka "brez predpostavk" pač pedagoška poenostavitev). Vendar je ravno zaradi aksiomatično razumljene legitimnosti deskriptivne analize po določeni teoriji - v tem primeru 


\section{MUZIKOLOŠKI ZBORNIK • MUSICOLOGICAL ANNUAL XXXIV}

organicistični teoriji -, analitična praksa izpričala zgovorno razglasje glede umevanja pojma theöros (opazovalec, gledalec). Organicistična teorija o motivičnem prajedru ali celici, iz katere se razrašča celotna skladba - temeljna teorija instrumentalne glasbe 19. stoletja, po kateri so svoje analitične poglede izpeljali "energetiki" - se denimo v prvi vrsti kaže kot "teorija recepcije" ali - kot smerokaz slišanja določene tonske postavitve:

PRIMER 1, Ludwig van Beethoven, Sonata za klavir op. 10/3 v D-duru. ${ }^{8}$

Ludwig van Beethoven, Sonata za klavir op. 10/3.

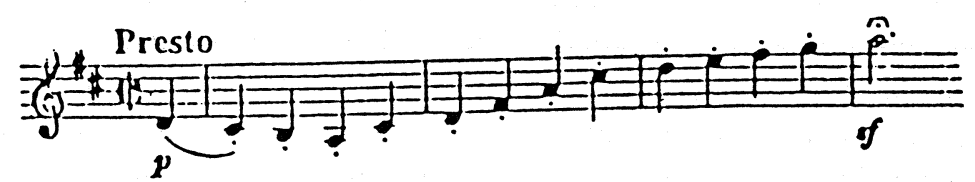

Hugo Riemann, Analyse von Beethoven Klaviersonaten I, Berlin 1918, 33 in dalje.

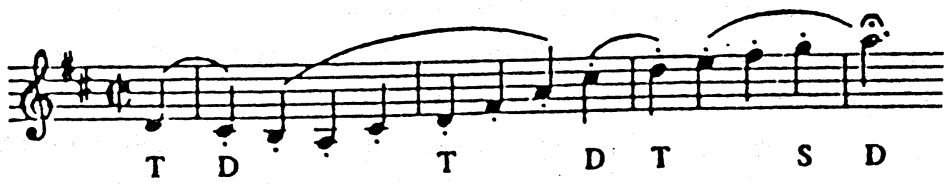

Jürgen Uhde, Beethovens Klaviermusik II, Stuttgart 1970, 176.

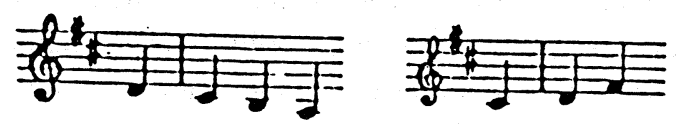

Carl Dahlhaus, Beetboven und seine Zeit, Laaber 1987, 130 in dalje,

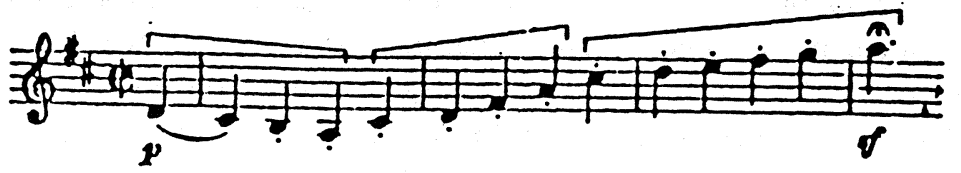

Dieter Schnebel, Das angegriffene Material. Zur Gestaltung bei Beethoven, v: Beethoven 70, Frankfurt 1970, 46.

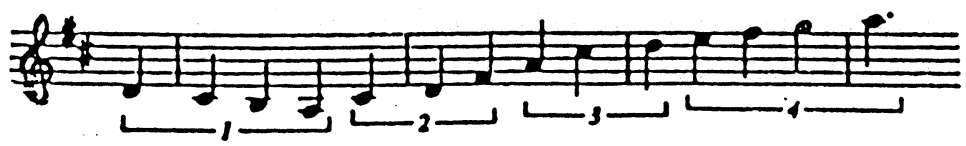

8 Primer navaja C. Kühn v zgovorno naslovljenem poglavju "Selbstverständnis und Aktualität", kjer sooči in označi kot medsebojno dopolnjujoči se analitični ishodišči: zgodovinsko pogojeno razčlenjevanje in iz analitikove lastne zgodovinske perspektive izhajajoče opazovanje. 
Različne oblike členjenja Beethovenove teme se očitno razhajajo po izhodiščni točki opazovanja, kar tvori $\mathrm{v}$ širšem smislu predmet (zgodovine) recepcije; Riemann členi temo po osnovnih harmonskih funkcijah, Jürgen Uhde podobno kot Rudolph Réti opazuje "motivično pracelico", Dahlhaus pristopa k temi holistično ("schenkerjansko") in Dieter Schnebel strukturalistično. Če je na primeru prve teme Beethovenove Sonate za klavir op 10/3 možno predstaviti njen ustroj na štiri načine, ki so - vsak po svoje - utemeljeni v različnih teoretičnih izhodiščih, se zdi vprašanje o zgradbi, denimo, celotnega stavka skorajda vnaprej podvrženo nadaljnjemu razvejevanju "pravilnih" odgovorov. Toda: "pravilni" odgovori, za kakršne bi lahko šteli vsi navedeni primeri razčlenbe Beethovenove teme, niso zasnovani na različnih analitičnih principih, saj so vsi prikaz teoretične postavke o organski gradnji. Avtorji ne izhajajo iz subjektivnega videnja pojava, temveč iz subjektivnega poudarka, ki ga pripisujejo posameznemu, izhodišnemu segmentu glasbene teorije. Riemann funkcionalni harmoniji, pri čemer je melodični obris drugoten; Uhde izhaja iz rétijevske pracelice; Dahlhaus opazuje temo kot motivično oziroma tematično in harmonsko zaključeno celoto; Schnebel si zastavlja "Prokrustovo posteljo" kvarte v smislu praintervala.

Deskripcija se v teh primerih kaže kot "sposobnosti prepoznavanja tipične transformacije dane tematske oblike," kot je zapisal Rudolph Réti. ${ }^{9}$ Kot sopomenka za deskripcijo se torej izkaže pojem "adekvatnega" razumevanja zvočnega, pri čemer je skorajda nemogoče vztrajati na enem samem postopku razčlenjevanja oziroma ga zagovarjati kot edino merodajno orodje za razkrivanje oblikovnih značilnosti. Recepcijski pristop torej priča v prvi vrsti o analitikovem umevanju obravnavane skladbe, pri čemer je njen zgodovinski kontekst drugoten. S tem, ko analitik razkriva značilnosti tonske zgradbe domnevno "brez predpostavk", ne zanika določene teoretične pogojenosti svojega stališča, temveč ga zgolj ne problematizira oziroma ga aksiomatično sprejme. Težko bi namreč ugovarjali dejstvu, kot meni Carl Dahlhaus, da je "določeno teoretično stališče, eksplicitno ali neizrečeno, izhodiščna točka vsake analize - ideja deskripcije brez predpostavk je fantom; in četudi bi jo lahko izpeljali, bi je ne bilo vredno realizirati." ${ }^{10}$

\section{Objektivnost opisov glasbenega stavka.}

1. Analitični metodi kot sta Tipologija melodične konture Charlesa R. Adamsa ${ }^{11}$ ali pa statistična členitev melodičnih intervalov Mervyna McLeana ${ }^{12}$ ponujata natančno

\footnotetext{
9 Rudolph Réti, Thematic Patterns in Sonatas of Beethoven, London 1967, 190.

10 Carl Dahlhaus, Analyse und Werturteil (Musikpädagogik 8, ur. Sigrid Abel-Struth, Mainz 1970, 16.

11 Charles R. Adams, Melodic Contour Typology, Ethnomusicology 1976/20,179-215.

12 Mervyn Mclean, A New .Method of Melodic Interval Analysis as Applied to Maori Chant, Ethnomusicology 1966, 10, 174-90.
} 
dodelan analitični inštrumentarij za "prepoznavanje dane tematske oblike". ${ }^{13}$ Formalistični analitični metodi, ki skušata kodificirati in sistematizirati fenomenološko "prepoznavanje", sta namenjeni statistični obdelavi glasbenega stavka. Njun namen je "izluščiti" tipologijo glasbenega stavka, podobno tisti, ki jo je za harmonijo strnil najprej J. Ph. Rameau, kasneje A. B. Marx ter na prehodu v 20. stoletje H. Riemann, in za Palestrinin slog J. J. Fux 1725. ter v 1920ih Knud Jeppesen. In vendar so izsledki McLeanove ali Adamsove analize parcialni. Njihov smoter ni razkriti "enkratnosti" melodične linije, napisane v tradiciji romantizma, kar je glavna ideja romantične teorije o glasbenem organizmu, ${ }^{14}$ saj oba analitična postopka ne upoštevata konteksta posameznega razkritega segmenta. (Šele prikaz prepletanja glasbenih prvin, ključne značilnosti zlasti romantične glasbe, bi tovrstnemu izsledku dodelila smisel v okviru posamezne skladbe, opusa ali pa zvrsti.)

2. Generativna teorija tonalne glasbe $e^{15}$ Freda Lerdahla in Raya Jackendoffa ponuja shematsko orodje za ponazoritev prepletanja vseh tonskih prvin v tonikalni glasbi. Je eden izmed poskusov univerzalizacije postopkov členjenja tonikalne glasbe, ki upošteva "kontekstualizacijo" tonskih dogodkov (kar manjka poprej omenjenima postopkoma členjenja), in ki nekoliko zavaja zaradi schenkerjanskega poudarjanja "Ozadja" ali "prastrukture" klasicistično-romantične muzike - kadence. ${ }^{16}$ Izsledki, ki so namenjeni sistematizaciji tonalne praosnove posameznih glasbenih "idiomov", zahtevajo nadaljnjo umestitev $\mathrm{v}$ določeno teoretično poglavje, ki pa ga avtorja ne iščeta $\mathrm{v}$ okviru zgodovinskega okolja analizirane tonske zgradbe, temveč v različnih poglavjih sistematične muzikologije. Svojo analitično metodo skušata umestiti med vrsto panog, ki sooblikujejo t.i. kognitivno znanost, med posamezne veje "psihologije, lingvistike, nevrofiziologije, filozofije in računalništva" (332). Se pravi, da smiselnost tovrstne schenkerjanske "diminucije" analitični izsledki dobijo takrat, ko primerjamo značilnosti večjega števila bodi drugih del istega skladatelja, bodi del sorodnega glasbenega idioma, saj je ravno na podlagi tovrstnih "pešračunov" in statističnih obdelav gradiva mogoče natančno razkriti tipično kompozicijsko gesto določene skladbe.

3. Podobno je $z$ analitično metodo Allena Fortea: ${ }^{17}$. Forte izhaja iz predpostavke, da vsebinskost tonske arhitektonike tvorijo sorodnostna razmerja med segmenti:

\footnotetext{
$13 \mathrm{~S}$ podobno namero kot Adams in McLean, torej z željo po objektivnem razkrivanju značilnosti melodike v netonikalni glasbi, se po Forteovi predlogi izpeljana metoda melodičnega členjenja S. E. Gilberta nedvomno kaže kot učinkovito in natančno orodje za prikaz diastematskih oblik. A kljub temu, da izhaja, podobno kot R. Reti, iz predpostavke, da je skladba predvsem melodično zasnovana zgradba, ne upošteva harmonskega, ritmičnega ali pa "dinamičnega" konteksta, iz katerega bi bilo melodiko težko izločiti. V tem primeru je melodična linija tako rekoč izrezana iz konteksta in podvržena t.i. imbrikaciji (zaporednemu razkrivanju intervalov od tona do tona), statistično dobljeni izsledki pa zahtevajo nadalinjo obravnavo.

14 Kljub temu, da oba postopka členjenja tonske zgradbe izhajata iz ameriškega etnomuzikološkega okolja, ponujata dodelanejše orodje za razčlenjevanje melodike mimo rétijevske analize.
}

15 Fred Lerdahl / Ray Jackendoff, A Generative Theory of Tonal Music, MIT Press, Cambridge 1983.

16 Ib., 115

17 The Structure of Atonal music, Yale University Press1973. 
nekakšnimi "prastrukturami" tonskih konstelacij. Njegova glasbena teorija nizov/množic ponuja način bierarbiziranja in vzporejanje diastematskih "prastruktur" med, denimo, celotnimi opusi skladateljev Schönbergovega kroga, kar bi morda prispevalo k slogovni kodifikaciji ekspresionizma. Vendar statistična obdelava, kakršni je podvrženo 208 oziroma 224 osnovnih nizov, zahteva nadaljno obdelavo konteksta, v katerem nastopajo določeni nizi oziroma segmenti, saj je celotna analitična metoda pomankljiva za razumevanje del, v katerih so skladatelji s seizmografsko "mehaniko" posegali po odtenkih ali medsebojnem prepletanju glasbenih prvin in vtonjenih misli.

Analitične metode Adamsa, Mcleana, Lerdahla in Jackendoffa ter Fortea torej kaže razumeti kot poskuse oblikovne taksonomije tonske zgradbe. Vse tri obravnavajo skladbo kot celoto (organizem) posameznosti. Topogledno je organicistična teorija, iz katere izhaja vrsta formalističnih analitičnih nastavkov, zgolj ena od postavk glasbene hermenevtike - natančneje glasbene retorike, enega izmed kompozicijsko-analitičnih konceptov posnemanja (mimesis), ki mu je mogoče slediti vsaj od prve polovice 16. stoletja.

Ian Bent ${ }^{18}$ organicizem sicer prišteva $\mathrm{k}$ omenjenim postajam analitičnih nastavkov in ga je mogoče upravičeno uvrstiti med temeljne analitične postavke, ki ustrezajo delom, nastalim od konca 18. do začetka 20. stoletja - predvsem zaradi bolj ali manj dodelanega schenkerjanskega inštrumentarija. Vendar teorije o glasbenem organizmu kljub temu kaže razumeti kot "splošen [in zgodovinsko nezamejen] glasbeni oblikotvorni princip, [...] ki se vselej spreminja z ozirom na zunajglasbeni pomen, katerega mu pripisuje določeno obdobje". Vendar: "Če ga razumemo v širšem smislu," piše Lotte Thaler, "obstaja nevarnost, da postane [...] brezpomenski topos; če pa ga razumemo v strogem, izključno goethejevskem morfološkem smislu, pravzaprav nikoli ni niti obstajal." ${ }^{19}$ Natančnost deskriptivnih postopkov razčlenjevanja glasbene sintakse je morda povedno videnje določenega glasbenega "teksta", vendar ne pove skorajda ničesar o duhovnem okolju, v katerem je bil analizirani "tekst" nastal. V končni fazi kvečjemu zastavlja še vprašanje, ali potemtakem pridevek "deskriptivno" ne ustreza vsakemu analitičnemu razčlenjevanju tonske gradbe? To bi bilo resda nesmiselno zanikati, a je ravno tako očitno, da statistična obdelava oblikotvornih značilnosti skladbe in prikazi konteksta, v katerem se le-ti pojavljajo, zahteva nadaljnjo muzikološko obravnavo.

\section{Cilj in smoter opisovanja glasbenega stavka.}

Razmejitev na preskriptivno in deskriptivno razčlenjevanje je $\mathrm{v}$ prvi vrsti videti smiselna kot nekakšno zgodovinsko križpotje sodobne analitične misli. V zgodovi-

18. Music Analysis in the Nineteenth Century I, Cambridge UP 1994, 1.

19 Organische Form in der Musiktheorie des 19. und beginnenden 20. Jahrhunderts, Musikverlag Emil Katzbichler 1984, 130. 
ni analitičnega opazovanja bi namreč skorajda ne mogli govoriti o analizi, pri kateri dobljeni izsledki ne bi zahtevali nadaljnje diferenciacije zgodovinsko-teoretičnega konteksta, iz katerega analizirano delo izhaja, oziroma analitikove izhodiščne namere. Forteova, Lerdahl / Jackendoffova, Michael Kasslerjeva, Haward Patrickova, F.T. Hofstetterjeva, in druge, z enako računalniško natančnostjo izpeljane deskriptivne analitične metode, namreč ne le dopuščajo, temveč nepreklicno zahtevajo nadaljnjo osmišljevanje (interpretacijo) izsledkov, tako da zgodovinsko oziroma teoretično ozadje opazovanega dela postane eden od členov v hermenevtični verigi "zgodovine učinkovanja" (Wirkungsgeschichte). ${ }^{20}$

$\mathrm{Z}$ možnostjo natančnega indeksiranja izsledkov, ki jo ponujajo omenjene metode, nastopi "navzkrižje med zgodovinsko pogojenostjo in preostalo [="fenomenološko"] vrednostjo analiziranega objekta," kakor je H.H. Eggebrecht označil naglavni problem analitičnih metod. ${ }^{21} \mathrm{Z}$ drugimi besedami: statistični indeks diastematskih razmerij je prepuščen analitikovi interpretaciji, ki lahko izhaja izključno iz 1. zgodovinsko-teoretičnih postavk obravnavane skladbe, ali pa iz 2. teoretičnih postavk analitikovega zornega kota. ${ }^{22}$ Navedene deskriptivne analitične metode torej zahtevajo razmejitev v smislu pedagoške delitve med ciljem analitičnih metod in smotrom analitičnega dela: če se vprašanje o cilju analitičnih metod izteka $\mathrm{z}$ iznajdevanjem metodoloških načinov členjenja prvin glasbenega stavka, je smoter analiziranja skorajda nemogoče posplošiti oziroma ga poenotiti: sodi $\mathrm{v}$ poglavje o spoznavnih kategorijah, ki jih narekuje sistematična muzikolologija. Deskriptivna analiza je tako rekoč "slepa", če se analitik ne sooči z razraščajočimi se zahtevami sistematične muzikologije: analitične metode so odvisne od zastavljenega cilja, le-ta pa ni odvisen samo od dejanskega notnega zapisa ali njegove praktične izvedbe, kot je razvidno iz PRIMERA 1, temveč ga določa tudi - in predvsem - široka paleta legitimnih recepcijskih spremenljivk.

20 Razmejitev torej nakazuje na osnovno zagato stroke, v kateri je - še posebej z dajanjem prednosti "recepcijski zgodovini" po eni plati in, po drugi, sistemizirajočim postulatom sistematične muzikologije -, postal vprašljiv sam pojem glasbenega dela kot "v sebi zaključene" umetniške tvorbe. $Z$ drugimi besedami: če je za analitično opazovanje tonske zgradbe od antike dalje očitno, da so pisci vse tonske pojave razčlenjevali po aktualni preskriptivni kompozicijski teoriji - bodi po analogijah $\mathrm{z}$ aritmetičnimi proporci univerzuma, bodi $\mathrm{z}$ jezikovnim (stavčnim) ustrojem, bodi po semantičnih analogijah s posameznimi pojmi -, je od "energetskih" teorij dalje, mogoče slediti nekakšni "zgodovinski emancipaciji" analitičnega inštrumentarija. Rdeča nit, ki povezuje večino kompozicijsko-analitičnih teorij 20. stoletja, je proučevanje oblikotvornih vodil (D. de la Motte: "musikalische Denkmethode") ali glasbenih logik, pri razkrivanju katerih so analitiki urejali izsledke, denimo, s pomočjo psihologije oziroma fizikalizma (A. Halm, H. Schenker, E. Kurth, H. Mersmann), "deskripcije" (A. Schönberg), matematike (P. Boulez, M. Babbitt, A. Forte, J. Rahn), informacijske teorije (L.B. Meyer), lingvistike (A. Sychra, F. Lerdahl, R. Jackendoff) itn. Za tovrstno analitično opazovanje glasbenega stavka je značilno umevanje skladbe kot mreže medebojno povezanih ali pa neodvisnih "tonsko gibljivih oblik", $s$ čimer se predmet glasbene analize šele razkrije v ključnem vprašanju deskripcije: "Kaj določena tonska postavitev pomeni?". Vprašanja o njihovi semantičnosti - obrobna v pitagorejski aritmetiki, $\mathrm{v}$ teoriji baročnih afektov ali figur in $\mathrm{v}$ poetizirajočih ter hermenevtičnih interpretacijah glasbe klasicistične in romantične tradicije - deskriptivne analitične metode tako navezujejo na širše področje hermenevtike. S tem se tudi analitična praksa sooča $z$ vprašanji o identiteti opazovalca in ne le opazovanega.

$21 \mathrm{MZ}, \mathrm{XVII} / 1,1981,49$

22 Vprašanjem tipa - Kaj določena oblikovna struktura pomeni?, oziroma: Kaj ji podeljuje določen (ne le sintaktični) "pomen"? -, je s pomočjo deskriptivnih analitičnih nastavkov denimo pristopil etnomuzikolog Alan Lomax. V 1960-ih je predstavil zanimiv poskus celostne analize $s$ svojim kantometričnim (cantometrics) projektom, vendar - če izvzamemo Nattiezov semiološki tripartitni analitični sistem - se kažejo v praksi podobna raziskovanje na področju resne glasbe danes prej neke vrste "pozitivistična ezoterika", kakor koristna spoznavna možnost. (Prim.: Alan Lomax, Folk Song Style and Culture, American Association for the Advancement of Science 1968. Jean-Jacques Nattiez, Musicologie générele et sémiologe; ang. prev. C. Abbate, Music and Discourse: toward a semiology of Music, Princeton University Press 1990.) 
To je druga zahteva, ki jo je treba upoštevati pri deskripciji glasbenega stavka; $\mathrm{v}$ najširšem smislu bi jo lahko zaobjeli kot: iskanje muzikološkega konteksta, v okviru katerega je analitično delo smotrno oziroma smiselno. Na tej točki pojem deskripcije prehaja na področje hermenevtike ("razumevanja") tonskega stavka, $\mathrm{s}$ čimer se razpre široko problemsko polje, ki ga tvori splet recepcijskih, teoretičnih in ideoloških spremenljivk. ${ }^{23}$

\section{Smoter in smotri opisovanj glasbenega stavka.}

Stephen Hinton je leta 1987 zapisal v poročilu o Drugem angleškem kongresu glasbene analize, da je očitna "pravcata difuzna podoba analitične prakse," v kateri da "ni mogoče najti čvrstega skupnega imenovalca". ${ }^{24}$ Tudi na podlagi zbornika Secondo convegno europeo di analisi musicale ${ }^{25}$ iz leta 1992 bi težko govorili o jasno upredaljenih stališčih, po katerih naj bi bila glasbena analiza "tudi 'disciplina' z lastnim avtonomnim poljem raziskovanja", kot menita urednika zbornika, ki sta

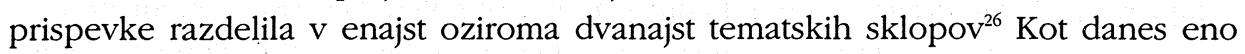
izmed zbirnih poglavij glasbene analize bi lahko označili tematski sklop, ki je v zborniku deseti po vrsti: Analiza analize: ali obstajajo povezave med različnimi analitičnimi metodami? V njem glasbeniki replicirajo na sestavek J. J. Nattieza, ki je razvrstil in na Mozartovi Simfoniji št. 40 primerjal analitične pristope 20. stoletja $\mathrm{v}$ dveh večjih skupinah. ${ }^{27} \mathrm{~V}$ prvi skupini so tiste analitične metode, "ki dopuščajo [...] emotivne, afektivne, imaginacijske konotacije" ali "semantično naravnane analize"28; drugo skupino, ki se osredotoča na "imanentno strukturo"29 obravnavanega dela, je Nattiez razdelil na dve podskupini - v prvo uvršča "taksonomične analize,

23 O obstoječih analitičnih metodah, naprimer, Nicholas Cook razmišlja takole: "Obstaja vrsta jasno oblikovanih tehnik glasbene analize;
vendar ni vedno ravno jasno, kaj nam te tehnike o glasbi pravzaprav povedo." (A Guide to Musical Analysis, Oxford UP 19944, 215.) Cook
namreč opazuje glasbeno analizo v okviru muzikologije, v naravnanosti katere da je iskati vzroke za zadrego današnjega analitičnega
dela, ki je redkokdaj izpostavljeno obema skrajnostima - historično-teoretičnemu ali "kontekstualnemu" pristopu po eni plati in, po dru-
gi, kognitivno-recepcijsko oziroma "antropološko" naravnanemu umevanju glasbenih pojavov. Tako kot Dahlhaus ali Eggebrecht, tudi
Cook postavlja analiżo kot razmeroma profilirano muzikološko dejavnost v širši okvir raziskovanja glasbe Zahoda: v splet teoretičnih, psi-
hološko-recepcijskih in zgodovinskih fenomenov, ki da jih je v glasbeni praksi smiselno razkrivati predvsem kot delce ali odseke t.i.
procesa "inkulturacije", torej kot člene v recepcijski "zgodovini učinkovanja". Z aristokratsko distanco Cook sprejema pravzaprav vsako
analitično dejavnost z navidezno ohlapnimi kazalci, ki se raztezajo med "smiselno", "nekoliko manj smiselno" in "nesmiselno"; ne pod-
cenjuje formalističnih "analitičnih piruet" Bouleza in Stockhausna, ki da so bile, pravi, "neodgovorne" in "naravnost nemuzikalne" (233),
saj so tudi te: "vitalni del glasbene kulture" dvajsetega stoletja (233).

24 Prim.: Hinton, Stephen, Cambridge University Music Analysis Conference 1986, Musiktheorie 1987/1, Laaber-Verlag.

25 Zbornik je 1992. izdala Universita degli Studi di Trento (ur. Rossana Dalmonte in Mario Baroni, 7).

26 Naslovi so: Analiza poustvarjalnosti: problemi in metode; Strukturalne teorije in kognitivni procesi pri segmentaciji glasbenega stavka; Melodične strukture in verbalna intonacija; Analiza modalnih struktur; Postopki strukturiranja in spremenljivke izvedb v repertorijih ustne tradicije; "Popularna glasba": analiza pesmi nastalih od 1950ih do danes; Strukturne povezave med glasbo in vizualno naracijo; Analiziranje elektro-akustične glasbe: $k$ definiranju zvočnih objektov; Vloga glasbene analize v osnovni in srednji šoli; Analiza analize: ali obstajajo povezave med različnimi analitičnimi metodami?; Prikaz računalniških programov; Različni prispevki. (Ib., 539.)

27 Ib., 529.

28 Tiste, "celles qui admittent - et méme qui soulignent - les connotations émotives, affectives, imageantes de l'oeuvre musicale," ali "analyses à orientation sémantique".

29 "Celles qui portent sur les structures immanentes de loeuvre." 
ki v enovitosti razkrivajo glasbeno substanco"30 (Ruwet, Réti, Meyer, LerdahlJackendoff), in $\mathrm{v}$ drugo tiste, ki razkrivajo "linearnost" Narmour, Lerdahl-Jackendoff). Klasifikacija, ki je na drugem svetovnem kongresu o glasbeni analizi izzvala vrsto komentarjeve, izkazuje pravzaprav še vedno živo dihotomijo, grobo rečeno, med "programskim" (subjektivnim) in "čisto, absolutno" (objektivno) mišljenim glasbenim pomenom. Kaže, da le-ta izhaja iz duhovnega okolja antinomij, ki jih racionalizirajoče načelo "jasnosti in razumljivosti" predstavlja kot večno razmejevanje med subjektivno imaginacijo in objektivno oblikovno faktografijo - kot razmejitev med subjektivistično "tradicijo asociativnega zaznavanja zvočnega"32 in "objektivnim" oblikotvorjem. ${ }^{33}$

Ena od glavnih tem za udeležence desete sekcije omenjenega simpozija je ob omenjenem izhajala iz vprašanj o objektivnosti in subjektivnosti analitičnega opazovanja. ${ }^{34}$ Po mnenju urednika simpozijskega zbornika M. Baronija je celotna razprava še posebej poudarila vprašanje razmerja med objektivnostjo analize ("l'obiettivo di fondo che ogni analisi sottointendo") in subjektivnim dejavnikom ("il punto di vista dell' analizzatore") ${ }^{35}$ - osrednjo problematiko današnje analize. Vprašanje razmerja med subjektom in objektom, sicer enega od ključnih problemov, ki se znova zastavlja skorajda ob vsakem analitiškem opazovanju, je Jonathan Dunsby postavil, z besedami N. Luhmanna, na področje "opazovanja drugega reda". $Z$ drugimi besedami: na epistemološko področje, ki se ukvarja $s$ "kontekstom" opazovanja, v katerem so zaobjete ne le značilnosti glasbenega stavka, temveč tudi njihovo ozadje, ki ga Dunsby definira po temeljnem načelu recepcijske zgodovine: "the work of art is complete in its identity." 36

$Z$ vprašanjem o identiteti skladbe objektivnost deskriptivno-formalistične analize pravzaprav izgubi vrednotenjski kategoriji pravilno-nepravilno, ki sta bili ključni premisi preskriptivnega analiziranja. Prepoznavnosti skladbe tako ne zagotavlja samo njena imanentna strukturiranost (čeprav je ta osnova, iz katere analitik

30 "Les analyses taxinomixues qui découpent en unités la substance musicale."

31 "Les analyses que, faute de mieux, jappellerai linéaires."

32 Prim. Erich Reimer, Hermann Kretzschmars musikalische Hermeneutik und die Tradition des assoziativen Hörens, v: Die Musikforschung 43/3, Kassel 1990, 211-221.

33 Albrecht Schneider in Uwe Seifert sta 1. 1986 ponudila Nattiezovi podobno, morda zgovornejšo razmejitev analitičnih pristopov: v prvo skupino sta uvrstila "oblikovne, kvantitativne [analitične] nastavke", v drugo pa, med drugimi, "fenomenološko, semiotično in kognitivno-psihološko" naravnano analizo. (Acta Musicologica LVIII, 1986/II, 305-338.) Če je za analitične nastavke, ki sta jih Schneider in Seifert uvrstila $v$ prvo skupino, značilno, da njihov namen ne presega naloge "objektivne" klasifikacije tonskih pojavov - in pozitivistično razumljena "objektivnost" je, kot rečeno, osnovno gibalo sodobnega analitičnega opazovanja - je za drugo skupino ravno "objektivnost" ključna predpostavka, ki jo je vredno vedno znova preizprašeti. Klasificiranje značilnosti tonskega stavka namreč kaže razumeti kot izhodišče določanja in (raz(umevanja "pomena" tonskih pojavov.

34 Druga izstopajoča tema simpozija je razkrila živahna vprašanja o tem, kaj naj zaobjema celostna analiza glasbenega dela, torej o kontekstu analiziranja posamezne oblikovne zgradbe.

35 Prim. ib., 593.

36 Rossana Dalmonte in Mario Baroni, op. cit., 574. 
"bere"), temveč vrsta "družbenih dogovorov", ki jih narekujejo tako zgodovinski kontekst, kot estetika, teorija, filozofija in psihologija. S tem, ko opisovanje oblike postane orodje hermenevtike glasbenega stavka in skuša odgovoriti na vprašanja tipa - "Kaj nam ta analiza pove?" -, formalistična deskripcija eksplicitno ali pa prikrito gradi nekakšno "še-ne-dooblikovano" mrežo med vejami muzikološkega $\mathrm{v}$ (denja, ki so same sicer utrjene, uveljavljene (po T. Kuhnu) kot "normalne znanstvene paradigme" ${ }^{37} \mathrm{z}$ bolj ali manj jasnim "kontekstom" raziskovanja, metodami dela in obsegom vprašanj.

Deskriptivne analitične pristope, ki so (bili) skozi zgodovino podvrženi vsakokratnemu umevanju glasbene substance, kaže tako razumeti kot predmet, ki naj ga usmerja po eni plati kompozicijska teorija, po drugi pa zgodovina in teorija (teorije?) recepcije. Nikakor ne njihov lastni, v nekaterih primerih do potankosti dodelan inštrumentarij. (Analiza po metodi A. Fortea, ki "naj-bi-bila-objektivna", v svoji izvirni obliki nujno potrebuje komentirje konteksta obravnavanega tonskega segmenta, in je brez določenega teoretičnega smotra, torej analitikove izhodiščne namere - neuporabna). In na tej točki se analitično opazovanje sooča $s$ ključno premiso zgodovine recepcije: s sistemi (konteksti, diskurzi, teorijami, zornimi koti ipd.) "identificiranja" glasbenih tvorb. Glavno analitično vprašanje torej ni več - Kakšno funkcijo ima določena oblikovna postavitev ali določen oblikotvorni postopek v skladbi? - temveč: Kaj "generira" pomen določenega kompozicijskega postopka? Se $s$ tem inštrumentarijem, ki se je do danes razvejeval na podlagi postulatov oblikoslovja A. B. Marxa, tudi analitik sooča s "pojmom razvoja in vprašanjem o cilju tega razvoja" analitičnih orodij, v čemer je po mnenju Hansa Georga Gadamerja ${ }^{38}$ ena od ključnih zagat tudi humanističnih znanosti? Vsaka analitično-kompozicijska kategorija ima namreč lastno zgodovino, vezano na različna poetološka, estetska, ali pa ideološka duhovna okolja. Slednjih sicer ne kaže obravnavati v smislu kopičenja različnih ( $\mathrm{v}$ posameznem obdobju aktualnih) postavk, temveč predvsem kot del semantične "kumulacije" sprememb glede na znano, ki jih analitik neizogibno ustvarja ob vsakokratni obravnavi določene tonske tvorbe. (O različnosti danes obstoječih konceptov analiziranja kaže torej premisliti zlasti $v$ njihovih "kontekstih", pri katerih je neizogibno govoriti o podobnih, v preteklosti "že zabeleženih težnjah...". Vladimir Karbusicky denimo zapaža: možnosti enega izmed največkrat omenjanih "odkritij glasbene poetike" 20. stoletja, variante dodekafonskega strukturiranja, je leta 1636 izračunal francoski glasbeni teoretik Marin Mersenne. $)^{39}$

37 Prim.: Thomas S. Kuhn, Die Struktur wissenschaftlicher Revolutionen, Suhrkamp (druga izdaja) 1969.

38 Das Erbe Europas, Suhrkamp Verlag, Frankfurt a.M. 1989, cit po hrv. prev. K. Miladinova, Nasljeđe Europe, Matica Hrvatska $1997,37$. 39 Vladimir Karbusicky, Zur Philosophie der kosmischen und irdischen Harmonie in der Musik, v: Das Gebrochene Gl(ckversprechen. Zur Dialektik des Harmonischen in der Musik, (ur. O. Kolleritsch) Wien-Graz 1998, 156. 
Če je torej odgovor na Gadamerjevo vprašanje pritrdilen, je potrebno iskati ustrezna pojmovanja analitičnih nastavkov v okviru širšega epistemološkega umevanja tonskih pojavov. Kriterije za to pa bržkone narekuje tako skladateljev miselni svet, kot tudi zgodovinsko in sedanje razumevanje le-tega. In če še enkrat pritrdim Gadamerjevi misli: uporabnost obstoječega deskriptivnega analitičnega inštrumentarija kaže upoštevati predvsem po njegovi posredniški funkciji - med umevanjem teoretičnih postulatov določenega obdobja, praktično izvedbo v notnem zapisu, in današnjim pomenom oziroma pomeni, ki ga oziroma jih tonski zapis izkazuje. Kar je, konec koncev, bila in tudi ostaja ena od osnovnih nalog analitičnega opazovanja.

\section{Musical and Analytical Points of Departure: Towards a Description of Compositional Structure}

Summary

The article deals with the concept of description of the compositional structure. It proceeds from several musical-analytic procedures or methods. In the first place, it concerns thequestions of "contextualization" of the description of music, in which some epistemological categories are discussed that generate musical meaning. Along with this the issue of analytic focal points within the framework of certain currently topical points of departure of the musical analysis is touched upon which raises two themes: the aim of musical analysis and the relation between the subjectivity and the objectivity of a particular description. 